Ann. Zootech., 1988, 37 (3), 159-180

\title{
Review
}

\section{Long-term effects of recombinant bovine somatotropin (rBST) on dairy cow performances ${ }^{(1)}$}

\author{
Y. CHILLIARD \\ INRA, Laboratoire de la Lactation, \\ Centre de Recherches de Clermont-Ferrand-Theix, F 63122 Ceyrat
}

Summary

Long-term (18-32 week) effects of recombinant BST (bovine somatotropin) injected daily (650 cows, 20 assays) or as prolonged release preparations ( 790 cows, injected each 14 or $28 \mathrm{~d}$., 23 assays) are reviewed. Daily injections of $10-15,20-27$ or 31-50 mg BST increased milk yield of $3.9,5.2$ or $5.6 \mathrm{~kg} / \mathrm{d}$ (respectively). Somidobove $(320,640$ or $960 \mathrm{mg}$ BST each $28 \mathrm{~d}$.) increased milk yield $2.2,3.1$ or $4.2 \mathrm{~kg} / \mathrm{d}$, and Sometribove $(500 \mathrm{mg} / 14 \mathrm{~d}$.) 4.4 . $\mathrm{kg} / \mathrm{d}$. Mean milk composition was unchanged, but cycled between injections in the case of prolonged release preparations. Dry matter intake increase for high BST doses was $1.5-1.7 \mathrm{~kg} / \mathrm{d}$ in 32-week experiments, and $0.8 \mathrm{~kg} / \mathrm{d}$ in 18 week-experiments. Energy balance and body condition score decreased during the first 3 months of BST treatment, due to delayed DM intake increase. In two experiments body lipids were sharply decreased in BST cows. Feed efficiency was increased (6-17 p. 100) according to dilution of maintenance requirement in total needs and to decreased body tissue deposition. There was no clear interaction of BST response with cow parity and milk yield potential, but a trend towards decreased response after several months of BST. High energy-high protein complete mixed rations tended to increase BST response, but inter-assay variability was high. Responses tended to be lower $(2.5 \pm 1.8 \mathrm{~kg}$ milk/d) at pasture in European conditions.

Key words : Somatotropin, dairy cow, energy utilization, long term, Europe.

Knowledge of the long-term (several months) effects of BST (bovine somatotropin, or growth hormone) in dairy cows has increased rapidly since 1985 , thanks to the increasing production of BST by recombinant DNA techniques. Since reviews by PEEL and Bauman (1987), Chilliard (1988) and Hart (1988) a great number of new results have appeared, both from America (1988, Am. Dairy. Sci. Assoc. Meeting) and Europe (see below). These results are more or less the first concerning the effects of BST in prolonged release preparations, that allow large scale field experiments in practical conditions.

(1) This paper was first presented at the seminar on « Use of Somatotropin in Livestock production " (Commission of the European Communities, programme of coordination of agricultural research, Bruxelles, 27-29 September 1988). 
This paper reviews the effects of long-term BST injections on dairy cow performances : milk production and composition, dry matter intake and energy balance, body weight and body condition changes, feed efficiency, in connection with BST dose levels, BST release preparations, cow parity, milk production potential, lactation stage, feeding and management factors.

\section{Short-term experiments}

Most of these experiments (1973-1986) were done by injecting the natural pituitary somatotropin. The first experiment with recombinant BST was published by BAUMAN et al. (1982).

During 18 short-term assays (less than 4 weeks, after the second month of lactation) the mean milk production response to BST (25-50 units/day) was $4.0( \pm 1.3)$ $\mathrm{kg} /$ day, whereas dry matter intake $(-0.5 \pm 1.1 \mathrm{~kg} /$ day $)$ and calculated energy balance $(-4.2 \pm 2.1 \mathrm{Mcal} /$ day) decreased (ChIlliard, 1988). Effects on milk composition differed according to the energy balance of the treated cows (table 1) in accordance with the well known general effects of energy balance on milk fat and protein contents (Journet and Chilliard, 1985 ; Rémond, 1985). Lactose content tended to increase $(+0.6 \pm 1.1 \mathrm{~g} / 1)$ whatever the energy balance of the cows.

TABLE 1

Short-term $\left(\begin{array}{lll}5-21 & \text { d.) }\end{array}\right)$ effects of BST on performances of dairy cows with different calculated energy balances (CEB) (a).

Effets à court terme (5-21 j) de la BST sur les performances des vaches laitières selon leur bilan énergétique calculé (a).

\begin{tabular}{|c|c|c|c|c|c|c|}
\hline \multirow{2}{*}{$\begin{array}{l}\text { CEB of } \\
\text { BST cows }\end{array}$} & \multicolumn{2}{|c|}{ Milk yield * } & \multirow{2}{*}{$\begin{array}{l}\text { Milk fat * } \\
(\mathrm{g} / \mathrm{l})\end{array}$} & \multirow{2}{*}{$\underset{(\mathrm{g} / \mathrm{l})}{\text { Milk protein * }}$} & \multirow{2}{*}{$\underset{(\mathrm{kg} / \mathrm{d})}{\mathrm{DMI}(\mathrm{d})}$} & \multirow{2}{*}{ CEB * } \\
\hline & $\mathrm{kg} / \mathrm{d}$ & $\%$ & & & & \\
\hline $\begin{array}{c}3.3 \\
( \pm 1.4)^{(b)}\end{array}$ & $\begin{array}{c}+4.5 \\
( \pm 1.6)\end{array}$ & $\begin{array}{l}+19.6 \\
( \pm 7.9)\end{array}$ & $\begin{array}{c}+0.8 \\
( \pm 2.3)\end{array}$ & $\begin{array}{c}-0.8 \\
( \pm 0.8)\end{array}$ & $\begin{array}{c}-0.2 \\
( \pm 1.1)\end{array}$ & $\begin{array}{c}-3.7 \\
( \pm 2.3)\end{array}$ \\
\hline $\begin{aligned} &-3.6 \\
&( \pm 3.9)(\mathrm{c})\end{aligned}$ & $\begin{array}{l}+3.5 \\
( \pm 0.7)\end{array}$ & $\begin{array}{c}+17.3 \\
( \pm 8.6)\end{array}$ & $\begin{array}{c}+3.1 \\
( \pm 2.5)\end{array}$ & $\begin{array}{l}-2.1 \\
( \pm 1.7)\end{array}$ & $\begin{array}{c}-0.8 \\
( \pm 1.0)\end{array}$ & $\begin{array}{c}-4.8 \\
( \pm 1.8)\end{array}$ \\
\hline
\end{tabular}

(a) See Chillard (1988) for references ; (b) 9 assays, 47 cows, CEB of BST cows $>1.1 \mathrm{Mcal} / \mathrm{d}$. ; (c) 9 assays, 46 cows, CEB of BST cows $<0.4 \mathrm{Mcal} / \mathrm{d}$. ; (d) Dry matter intake (mean \pm s.d.).

$\left({ }^{*}\right)$ BST-control.

The milk response (p. 100 or $\mathrm{kg} /$ day) was lower during the first two months of lactation than after peak yield (6 vs. $12-30$ p. 100) (ChIlliard, 1988). Response to increasing doses of BST was curvilinear (EPPARD et al., 1985). 


\section{Long-term effects of recombinant BST injections}

\section{A. Milk production and composition}

\section{Daily injections}

In 21 experiments on 969 dairy cows (mean duration of 32 weeks, beginning 5-13 weeks after calving) there was a dose-dependent response (table 2) : the mean (weighed

TABLE 2

Long-term effects of daily injections of recombinant BST on dairy cow milk yield. Effets à long terme d'injections journalières de BST recombinée sur la production laitière des vaches.

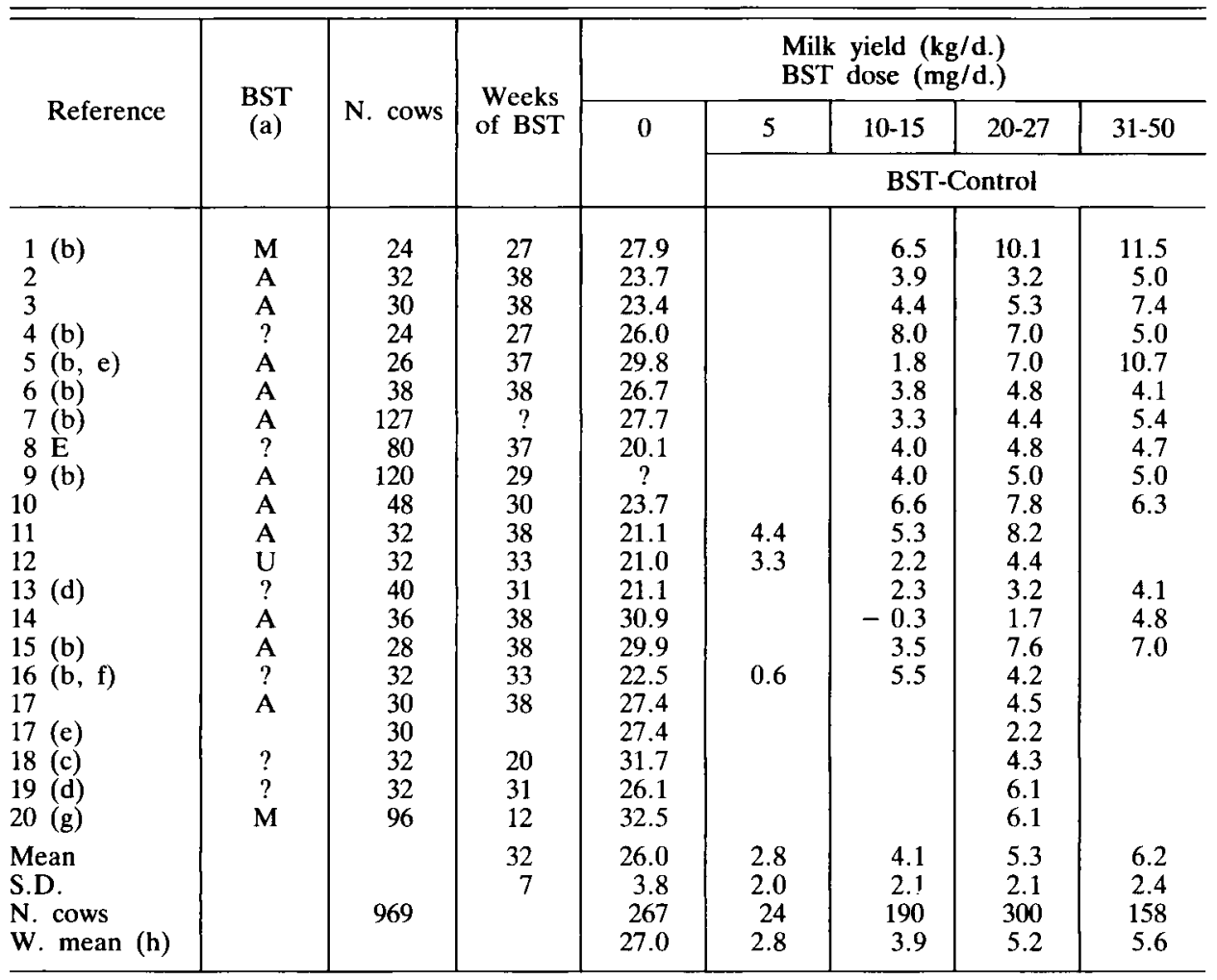

(a) $\mathrm{A}=$ American Cyanamid ; $\mathrm{M}=$ Monsanto ; $\mathrm{U}=$ Upjohn - (b) 3.5 p. $100 \mathrm{FCM}$ - (c) 4 p. $100 \mathrm{FCM}-$ (d) 305 d. lactation - (e) 2 nd BST consecutive lactation - (f) $50 \%$ of Jersey cows - (g) milking 3 times/day - (h) weighed mean (for cow number) - $\mathrm{E}=$ Europe.

(1) Bauman et al., 1985 ; (2) Baird et al., 1986 ; (3) Chalupa et al., 1986, 1987 a ; (4) HutChiSon et al., 1986 ;

(5) Annexstad et al., 1987 ; (6) Burton et al., 1987 ; (7) Chalupa et al., 1987 b ; (8) Thomas et al., 1987 ;

(9) Chalupa et al., 1988 ; (10) Eisenbeisz et al., 1988 b ; (11) Elvinger et al,, 1988 ; (12) MunNeke et al., 1988 ; (13) Nrtes et al., 1988 ; (14) Palmquist, 1988 ; (15) Soderholm et al., 1988 ; (16) WeSt et al., 1988 ; (17) Hemken et al., 1988 ; (18) Rowe-Bechtel et al., 1988 ; (19) Tessmann et al., 1988; (20) Agullar et al., 1988. 
for cow number) increase in milk production was $2.8 \mathrm{~kg} /$ day $(+11 \mathrm{p} .100$ over control cows) with $5 \mathrm{mg} \mathrm{BST} /$ day, and $5.6 \mathrm{~kg} /$ day with $31-50 \mathrm{mg} \mathrm{BST} /$ day (+ $21 \mathrm{p} .100 \mathrm{over}$ control cows). Inter-assay S.D. was $2.0-2.4 \mathrm{~kg} /$ day, i.e. the variation coefficient (p. 100$)$ of the response tended to decrease at higher doses, but was high (39 p. 100) even with $31-50 \mathrm{mg} \mathrm{BST} / \mathrm{d}$. The response to $\mathrm{rBST}$ was very rapid (maximum after one week or less). Few long-term assays have been conducted with the pituitary somatotropin (table 3). In two direct comparisons (BAUMAN et al., 1985 ; Hutchison et al., 1986), the response was lower than with the same dose $(27 \mathrm{mg} /$ day) of recombinant methionylBST.

The milk fat, protein and lactose contents were unchanged (mean values over the period). When significant changes are reported, they are of limited extent, and positive or negative in different studies.

TABLE 3

Long-term effects of pituitary BST on cow milk yield.

Effets à long terme de la BST hypophysaire sur la production laitière des vaches.

\begin{tabular}{|c|c|c|c|c|c|}
\hline \multirow{2}{*}{ Reference } & \multirow{2}{*}{ N. cows } & \multirow{2}{*}{$\begin{array}{c}\text { Dose } \\
\text { (mg/d.) }\end{array}$} & \multirow{2}{*}{$\begin{array}{l}\text { Weeks of } \\
\text { BST }\end{array}$} & \multicolumn{2}{|c|}{ Milk yield $(\mathrm{kg} / \mathrm{d})$} \\
\hline & & & & Control & BST-Control \\
\hline BRUMBY and HANCOCK, 1955 . & $2 \times 3$ (a) & 50 & 12 & 13.1 & 5.8 \\
\hline PEEL et al., 1985 & $2 \times 5$ (a) & 50 & 22 & 19.8 & 3.5 \\
\hline BAUMAN et al., 1985 & $2 \times 6$ & 27 & 27 & 27.9 & 4.6 \\
\hline Hutchison et al., $1986 \ldots \ldots$ & $2 \times 6$ & 27 & 27 & 26.0 & 2.0 \\
\hline Mean & & & & 21.7 & 4.0 \\
\hline
\end{tabular}

(a) Sets of twin cows.

\section{Prolonged release preparations}

Different companies are producing somatotropin molecules whose precise structure, as well as excipients used for prolonged release systems, are still proprietary information. Moreover, BST dose and injection frequencies differ between companies. As a consequence, results for each product will be presented separately in this chapter.

Somidobove (Eli Lilly) was used at three doses $(320,640,960 \mathrm{mg})$ and injected every $28 \mathrm{~d}$., corresponding theoretically to 11,23 and $34 \mathrm{mg} \mathrm{rBST} / \mathrm{d}$., respectively. Production responses (weighed means) on about 100 cows per dose (table 4) were 56, 60 and 75 p. 100 (respectively) of those obtained by daily injections in comparable amounts (table 2). Increasing the injection frequency $(28,21$ and $14 \mathrm{~d}$.) of the same total amount of BST did not change milk response to any large extent (McGuFFeY et al., $1987 \mathrm{~b}$; VÉRITÉ et al., 1988). Part of the difference with daily injections could also be due to feeding or management factors (see below). Milk fat and protein content were unchanged in most experiments. However increases were observed with 320/28 d. injections (Oldenbroek et al., 1987 ; Vérité et al., 1988 ; Vignon et al., 1988). 
TABLE 4

Long-term effects of Somidobove injections on dairy cow milk yield.

Effets à long terme d'injections de Somidobove sur la production laitière des vaches.

\begin{tabular}{|c|c|c|c|c|c|c|}
\hline \multirow{3}{*}{ Reference } & \multirow{3}{*}{ N. cows } & \multirow{3}{*}{$\begin{array}{l}\text { Weeks } \\
\text { of BST }\end{array}$} & \multicolumn{4}{|c|}{$\begin{array}{l}\text { Milk yield }(\mathrm{kg} / \mathrm{d} .) \\
\text { BST Dose }(\mathrm{mg} / 28 \mathrm{~d} .)\end{array}$} \\
\hline & & & \multirow[t]{2}{*}{0} & 320 & 640 & 960 \\
\hline & & & & \multicolumn{3}{|c|}{ BST-Control } \\
\hline $\begin{array}{l}21 \\
22 \text { (a) } \\
23 \text { E (b) } \\
24 \text { (d) } \\
25 \text { (c) } \\
26 \mathrm{E} \\
27 \mathrm{E} \\
28 \mathrm{E} \\
29 \mathrm{E} \text { (d) }\end{array}$ & \begin{tabular}{r|r}
14 \\
70 \\
48 \\
16 \\
188 \\
18 \\
36 \\
24 \\
40 \\
32
\end{tabular} & $\begin{array}{c}12 \\
12 \\
24 \\
16 \\
12-36 \\
24 \\
20 \\
12 \\
20\end{array}$ & $\begin{array}{l}22.9 \\
26.4 \\
20.9 \\
29.8 \\
26.8 \\
24.8 \\
21.0 \\
16.3 \\
17.7\end{array}$ & $\begin{array}{r}3.9 \\
0.9 \\
\\
2.7 \\
0.2 \\
-0.3\end{array}$ & $\begin{array}{l}4.9 \\
3.3 \\
2.4 \\
4.3 \\
2.7 \\
1.2 \\
0.1 \\
1.3\end{array}$ & $\begin{array}{l}4.1 \\
6.3 \\
2.9 \\
\\
4.8 \\
2.2 \\
\\
0.4\end{array}$ \\
\hline $\begin{array}{l}\text { Mean } \\
\text { S.D. } \\
\text { N. cows } \\
\text { W. mean (e) }\end{array}$ & 468 & $\begin{array}{r}18 \\
5\end{array}$ & $\begin{array}{r}23.0 \\
4.4 \\
129 \\
23.6\end{array}$ & $\begin{array}{r}1.5 \\
1.8 \\
99 \\
2.2\end{array}$ & $\begin{array}{r}2.5 \\
1.6 \\
136 \\
3.1\end{array}$ & $\begin{array}{r}3.4 \\
2.1 \\
104 \\
4.2\end{array}$ \\
\hline
\end{tabular}

(a) Mean of 14, 21 and $28 \mathrm{~d}$. injection frequencies - (b) mixed breeds - (c) pooled data from 5 herds (d) Montbéliarde cows - (e) weighed mean.

(21) McGuffey et al., 1987 a ; (22) McGuffey et al., 1987 b ; (23) Oldenbroek et al., 1987 ; (24) McGuffey et al., 1988 ; (25) MeYer et al., $1988 ;(26,27)$ Vérité et al., $1988 ;(28)$ VIGNON et al., 1988 ; (29) PARRASSIN and VIGNON, 1988; E = Europe.

Sometribove (Monsanto) was used as a $500 \mathrm{mg} / 14 \mathrm{~d}$. formulation, corresponding theoretically to $36 \mathrm{mg} \mathrm{rBST} / \mathrm{d}$. Milk yield increase in about 450 cows $(4.4 \mathrm{~kg} / \mathrm{d}$., +19 p. 100 over control, table 5) was 79 p. 100 of that obtained by daily injections (table 2). Higher responses $(8-13 \mathrm{~kg} / \mathrm{d}$.) have been obtained with $1800 \mathrm{or} 3000 \mathrm{mg} /$ 14 d. (EPPARD et al., 1988). Milk composition was unchanged in most experiments. However milk protein content was significantly increased $(+0.9$ to $1.0 \mathrm{~g} / \mathrm{l})$ in 4 experiments (Phipps, 1987 ; Bauman et al., 1988 ; SAmuels et al., 1988 ; White et al., 1988). This increase was observed during the end of lactation (PHIPPs, 1987) and it would be suitable to weight it for decreasing milk volumes to evaluate its quantitative significance.

A prolonged release preparation from American Cyanamid was also experimented (JeNNY et al., 1988) and gave 3.5 p. $100 \mathrm{FCM}$ responses of $4.9-4.0$ and $4.4 \mathrm{~kg} / \mathrm{d}$ for injections of $140-350$ and $700 \mathrm{mg}$ each $14 \mathrm{~d}$. during 26 weeks ( 9 cows/group). Milk production responses to different injection strategies are summarized in table 6.

Apart from the mean production and composition, it is of interest for milk recording and milk quality controls to know if there are some fluctuations during the period between two BST injections. The milk response to BST was indeed timedependent (Huber, 1987 ; Oldenbroek et al., 1987). Maximal response was observed 
TABLE 5

Long-term effects of Sometribove $(500 \mathrm{mg} \mathrm{BST/14}$ d.) on dairy cow milk yield. Effets à long terme de la Sometribove (500 mg BST/14 j) sur la production laitière des vaches.

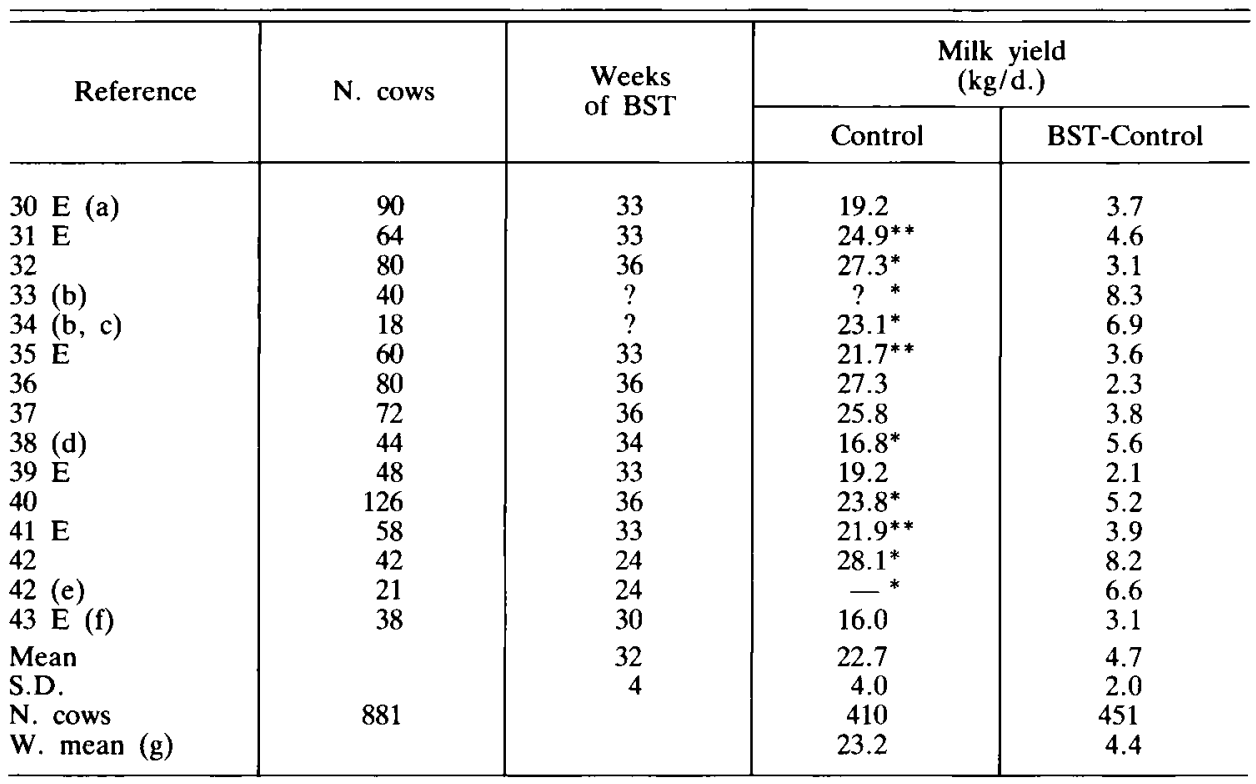

(a) Friesians - (b) $600 \mathrm{mg} / 14 \mathrm{~d}$. - (c) 2nd consecutive lactation - (d) Jerseys - (c) IM injections - (f) Normandes - (g) weighed mean; ${ }^{*} 3.5 \%$ FCM ; ${ }^{* *} 4 \%$ FCM.

(30) Phipps, 1987 ; (31) Ruphema et al., 1987, 1988 ; (32) Bauman et al., 1988 ; $(33,34)$ EpPaRd et al., 1988 ; (35) Gravert et al., 1988 ; (36) Huber et al., 1988 ; (37) Lamb et al., 1988 ; Anderson et al., 1988 ; (38) PelL et al., 1988 ; (39) RÉmond et al., 1988 ; (40) SAmUELS et al., 1988; (41) VedeAu and Schockmel, 1988; (42) White et al., 1988 ; LANZA et al., 1988 a; (43) Lossouarn, 1988. E = Europe.

\section{TABLE 6}

Effect of dose and frequency of BST injections on milk yield $(\mathrm{kg} / \mathrm{d})$.

Effet de la dose et de la fréquence des injections de BST sur la production laitière $(\mathrm{kg} / \mathrm{j})$.

\begin{tabular}{l|c|c|c|c|c|c|c}
\hline $\begin{array}{c}\text { Dose (mg) } \\
\text { Frequency (days) }\end{array}$ & $\begin{array}{c}10-15 \\
1\end{array}$ & $\begin{array}{c}20-27 \\
1\end{array}$ & $\begin{array}{c}31-50 \\
1\end{array}$ & $\begin{array}{c}320(\mathrm{a}) \\
28\end{array}$ & $\begin{array}{c}640(\mathrm{a}) \\
28\end{array}$ & $\begin{array}{c}960(\mathrm{a}) \\
28\end{array}$ & $\begin{array}{c}500(\mathrm{~b}) \\
14\end{array}$ \\
\hline Mean . . . . . . . . . . . . . . . . . . . . & 4.1 & 5.3 & 6.2 & 1.5 & 2.5 & 3.4 & 4.7 \\
S.D. . & 190 & 3.1 & 2.4 & 1.8 & 1.6 & 2.1 & 2.0 \\
N. cows . . & 3.9 & 5.2 & 5.6 & 2.2 & 3.1 & 4.2 & 4.4 \\
W. Mean ... & 158 & 99 & 136 & 104 & 451 \\
\hline
\end{tabular}

(a) Somidobove ; (b) Sometribove. 
about one week after each injection (PhIPPS, 1987 ; LAMB et al., 1988 ; RÉmond et al., 1988). Negative responses can be obtained during the 4th week in the case of $28 \mathrm{~d}$. injection cycles (VÉrité et al., 1988, figure 1).

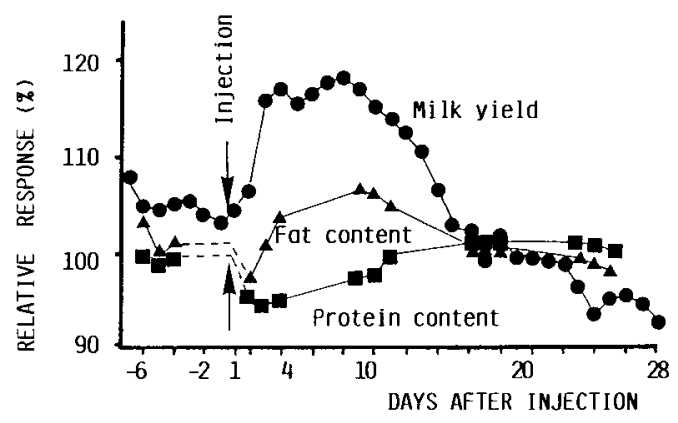

Fig. 1

Daily evolutions of milk yield and composition following prolonged release somatotropin injection (VÉRITÉ et al., 1988).

Evolutions journalières de la production et de la composition du lait après injection de somatotropine à libération prolongée.

Values are related to the means of days -7 to -1 and 20 to 28 , over five 28-day injection periods.

Cyclic responses in milk fat and/or protein contents between $14 \mathrm{~d}$. or $28 \mathrm{~d}$. injections have also been observed (PhipPs, 1987 ; Oldenbroek et al., 1987 ; Barbano et al., 1988 ; BAUMAN et al., 1988 ; LAMB et al., 1988 ; RÉmOND et al., 1988 ; VÉRITÉ et al., 1988, figure 1) except by WHITE et al. (1988). The cyclic pattern is still not well known and varied between studies. Milk protein content was generally lower after each injection and higher (up to $2 \mathrm{~g} / \mathrm{l}$ ) just before the following injection (Barbano et al., 1988 ; RÉmond et al., 1988 ; Vérité et al., 1988). Milk fat content can increase (up to 5 $\mathrm{g} / \mathrm{l}$ ) in parallel with milk yield (LAMB et al., 1988 ; VérITÉ et al., 1988), probably due to increased body lipid mobilization when yield is maximal (see below). Long chain fatty acid content of milk fat also cycled between two injections (Farries and Profitruich, 1987 ; LYNCH et al., 1988 ; VÉRITÉ et al., 1988). There was (RÉmond et al., 1988) or not (BAuman et al., 1988) cyclic change in lactose content.

\section{B. Dry matter intake (DMI) and calculated energy balance (CEB)}

In 14 daily-injection experiments, DMI increased from $0.6 \mathrm{~kg} / \mathrm{day}$ for $10-15 \mathrm{mg}$ $\mathrm{BST} / \mathrm{d}$, to $1.7 \mathrm{~kg} /$ day for $31-50 \mathrm{mg} \mathrm{BST} / \mathrm{d}$. The response variability was higher than 45 p. 100. In 6 Somidobove experiments, DMI increased from 0.2 to $0.8 \mathrm{~kg} / \mathrm{d}$., depending on the injected dose. Response in 9 Sometribove experiments was $1.5 \mathrm{~kg} / \mathrm{d}$. (table 7). DMI was not increased in one experiment with American Cyanamid preparations (JENNY et al., 1988). 
TABLE 7

Effect of dose and frequency of BST injections on DM intake $(\mathrm{kg} / \mathrm{d}$.).

Effet de la dose et de la fréquence des injections de BST sur l'ingestion de matière sèche $(\mathrm{kg} / \mathrm{j})$.

\begin{tabular}{|c|c|c|c|c|c|c|c|}
\hline $\begin{array}{c}\text { Dose (mg) } \\
\text { Frequency (days) }\end{array}$ & $\begin{array}{c}10-15 \\
1\end{array}$ & $\begin{array}{c}20-27 \\
1\end{array}$ & $\begin{array}{c}31-50 \\
1\end{array}$ & $\begin{array}{c}320(\text { a) } \\
28\end{array}$ & $\begin{array}{c}640(a) \\
28\end{array}$ & $\begin{array}{l}960 \text { (a) } \\
28\end{array}$ & $\begin{array}{c}500(\mathrm{~b}) \\
14\end{array}$ \\
\hline Mean & +0.6 & +1.7 & +1.7 & +0.5 & +0.7 & +0.7 & +1.5 \\
\hline S.D. & 0.7 & 0.9 & 0.8 & 0.5 & 0.4 & 0.4 & 0.5 \\
\hline N. cows & 116 & 166 & 92 & 89 & 98 & 94 & 337 \\
\hline W. Mean ...... & +0.6 & +1.5 & +1.7 & +0.2 & +0.8 & +0.8 & +1.5 \\
\hline References (c) & \multicolumn{3}{|c|}{$(1-3,5-8,10-11,14-18)$} & \multicolumn{3}{|c|}{$(21-26)$} & (d) \\
\hline
\end{tabular}

(a) Somidobove ; (b) Sometribove ; (c) see table 2, 4, 5 ; (d) 30-32, 35-36, 40-41.

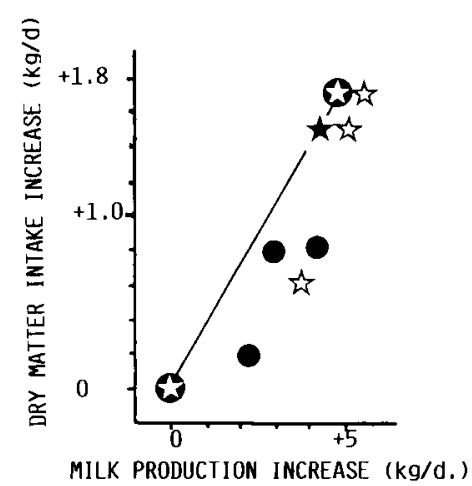

FIG. 2

Relationship between milk production and DM intake increases in untreated and BST treated cows.

Relation entre les accroissements de production laitière et d'ingestion de matière sèche chez des vaches traitées ou non par la BST.

Increase in untreated cows yielding 25 and $30 \mathrm{~kg} / \mathrm{d}$. (Faverdin et al., INRA, 1987).

Daily BST injections

\begin{tabular}{l|l} 
- Somidobove injections \\
$\star$ Sometribove injections
\end{tabular}

Increase of DM intake in BST cows $(20-50 \mathrm{mg} / \mathrm{d}$ and Sometribove) was exactly that predicted in untreated cows whose milk yield increased to the same extent (figure 2). This is in accordance with the view that BST cows are in some ways similar to genetically higher yielding cows (Peel and Bauman, 1987 ; Chalupa and Galligan, 1988). 
When not given by authors, EB (table 8) was calculated on a net energy basis from DMI, energy concentration of the diet, and 3.5 or 4 p. 100 fat corrected milk yield. These calculations should be considered cautiously, particularly when energy content of the diet was not given by authors in abstracts, and roughly estimated (1.5-1.65 Mcal $/ \mathrm{kg} \mathrm{DM}$ ) according to diet composition.

TABLE 8

Effect of dose and frequency of BST injections on calculated energy balance (Mcal/d.). Effet de la dose et de la fréquence des injections de BST sur le bilan énergétique calculé (Mcal/j).

\begin{tabular}{|c|c|c|c|c|c|c|c|}
\hline $\begin{array}{c}\text { Dose (mg) } \\
\text { Frequency (days) }\end{array}$ & $\begin{array}{c}10-15 \\
1\end{array}$ & $\begin{array}{c}20-27 \\
1\end{array}$ & $\begin{array}{c}31-50 \\
1\end{array}$ & $\begin{array}{l}320(a) \\
28\end{array}$ & $\begin{array}{l}640(a) \\
28\end{array}$ & $\begin{array}{l}960(a) \\
28\end{array}$ & $\begin{array}{c}500 \text { (b) } \\
14\end{array}$ \\
\hline Mean & -1.9 & -1.2 & -2.0 & -0.8 & -1.2 & -1.7 & -0.2 \\
\hline S.D. & 1.3 & 1.6 & 1.1 & 1.2 & 0.8 & 1.0 & 0.7 \\
\hline N. cows & 122 & 172 & 98 & 89 & 98 & 94 & 388 \\
\hline W. Mean .. & -1.8 & -1.2 & -1.5 & -1.4 & -1.4 & -1.9 & 0.0 \\
\hline References (c) & \multicolumn{3}{|c|}{$(1-8,10-11,14-18)$} & \multicolumn{3}{|c|}{$(21-26)$} & (d) \\
\hline
\end{tabular}

(a) Somidobove ; (b) Sometribove ; (c) see table 2, 4, 5 ; (d) 30-32, 34-38, 40-42.

Daily BST injections decreased CEB from 1.2 to $1.8 \mathrm{Mcal} / \mathrm{d}$ (table 8 ). This decrease was smaller for medium dose BST injections where DMI increase was the higher relatively to milk yield increase (tables 6 and 7). In Somidobove experiments CEB decreased 1.4-1.9 Mcal/d., whereas it was unchanged in Sometribove experiments. This result could appear surprising since energy needs for $4.4 \mathrm{~kg}$ extra-milk are higher than $3 \mathrm{Mcal}$, which would suppose an energy value higher than 2 Mcal N.E. $/ \mathrm{kg}$ extraDMI (cf. table 7). This is in fact not surprising if the net energy contents of the diets differ according to the milk production level of the cows. Indeed, if $20 \mathrm{~kg}$ DMI $\times 1.59$ $\mathrm{Mcal} / \mathrm{kg}=31.8 \mathrm{Mcal}$, and $21.5 \mathrm{~kg} \mathrm{DMI} \times 1.62 \mathrm{Mcal} / \mathrm{kg}=34.8 \mathrm{Mcal}$, the energy value of the extra $1.5 \mathrm{~kg}$ DM would be $2 \mathrm{Mcal} / \mathrm{kg}$. On the other hand, EB calculations are somewhat imprecise due to the limitations pointed out above, and possibly to different methods used by authors in estimating the energy density of the diets.

The lower response in DM intake with Somidobove is probably due in part to the experimental periods (18 \pm 5 weeks, table 4$)$ which are shorter than in daily-injection (32 \pm 7 , table 2$)$ or Sometribove ( $32 \pm 4$, table 5 ) experiments. Indeed, DM intake increase was always delayed, and did not become significant before 6-8 weeks of BST treatment (BAUMAN et al., 1985 ; PhIPPS, 1987 ; ANDERSON et al., 1988 ; EPPARD et al., 1988 ; Dhiman et al., 1988 ; LANZa et al., 1988 a). As a consequence, energy balance of treated cows was lower than that of control cows during the first 2 or 3 months of BST administration (BAumAn et al., 1985 ; PhIPPs, 1987 ; ANderson et al., 1988 ; Dhiman et al., 1988 ; EPPARD et al., 1988 ; Huber et al., 1988 ; LANZA et al., 1988 a ; RÉmond et al., 1988 ; SAMUels et al., 1988). 
From Sometribove data summarized by PeEL et al. (1988), it was possible to compute EB of the cows during the first 12 weeks and the last 22 weeks of eight 34-week experiments (table 9). CEB of treated cows was higher during the last 22 weeks (due to higher DM intake), and this can compensate completely for lower CEB during the first 12 weeks. However, delayed conception and increasing intercalving intervals (6-21 days in trials beginning during week 9 of lactation) were consequence of this lower CEB during the third month of lactation (see HARD et al., 1988 ; PEeL, 1988 and PeEL et al., 1988).

TABLE 9

Milk yield and calculated energy balance in 8 Sometribove experiments, during the first

12 weeks and the last 22 weeks of BST treatment (315 treated cows) (a).

Production laitière et bilan énergétique calculé dans 8 essais "Sometribove", pendant les 12 premières et les 22 dernières semaines des injections de BST (315 vaches traitées) (a).

\begin{tabular}{l|c|c|c|c}
\hline \hline \multirow{2}{*}{ Period } & \multicolumn{2}{|c|}{ Milk yield $(\mathrm{kg} / \mathrm{d})}$. & \multicolumn{2}{c}{ Calculated energy balance * } \\
\cline { 2 - 5 } & Control & BST-Control & Mcal/d & Mcal/period \\
\hline \multirow{2}{*}{ First 12 Weeks } & $\begin{array}{c}29.5 \\
( \pm 2.4)\end{array}$ & $\begin{array}{c}4.6 \\
( \pm 1.0)\end{array}$ & $\begin{array}{c}-2.1 \\
( \pm 0.7)\end{array}$ & -176 \\
\hline \multirow{2}{*}{ Last 22 Weeks } & $\begin{array}{c}21.0 \\
( \pm 3.5)\end{array}$ & $\begin{array}{c}3.4 \\
( \pm 1.1)\end{array}$ & $\begin{array}{c}+1.2 \\
( \pm 1.0)\end{array}$ & +185 \\
\hline
\end{tabular}

(a) Data from PeEL et al. (1988) and references 30-32, 35-37, 40-41 of table 5 .

* BST-Control - The same diet was used throughout each 34-week assay.

\section{Body weight, and body reserves of the cows}

In high yielding cows, body reserves (mainly lipids) are mobilized during the first 2 months of lactation, and deposited again during decreasing lactation (see CHILLIARD, 1987, for review).

Few data are available on body weight and body condition score changes in BST experiments, so results from tables 10 and 11 have to be regarded cautiously. Body weight and body condition change data are however roughly in accordance with energy balance data, if we take into account that experimental periods were shorter for Somidobove treatment (daily CEB $\times$ day number).

During Sometribove experiments, some authors also observed a lower body condition in BST cows during the first period of treatment, this difference being partly reversed during the following period, in accordance with CEB data (HuBER et al., 1988 ; SAMUELs et al., 1988). This was however not observed in another trial in European conditions ( -0.4 and -0.6 points of body condition score during winter and grazing periods, respectively) (RÉmOND et al., 1988). A lower body condition of BST treated cows $(-0.5$ point $)$ can also be reversed during the dry period before the next calving (PHIPPs, 1987). 
TABLE 10

Effect of dose and frequency of BST injections on body weight change (kg) (d). Effet de la dose et de la fréquence des injections de BST sur les variations de poids vif (kg) (d).

\begin{tabular}{l|r|r|r|r|r|r|c}
\hline \hline $\begin{array}{c}\text { Dose (mg) } \\
\text { Frequency (days) }\end{array}$ & $\begin{array}{c}10-15 \\
1\end{array}$ & $\begin{array}{c}20-27 \\
1\end{array}$ & $\begin{array}{c}31-50 \\
1\end{array}$ & $\begin{array}{c}320(\mathrm{a}) \\
28\end{array}$ & $\begin{array}{c}640(\mathrm{a}) \\
28\end{array}$ & $\begin{array}{c}960(\mathrm{a}) \\
28\end{array}$ & $\begin{array}{c}500 \text { (b) } \\
14\end{array}$ \\
\hline Mean . . . . . . & -14 & -23 & -43 & 0 & -5 & -18 & NS \\
S.D. . . . . . & 36 & 33 & 17 & 14 & 13 & 10 & - \\
N. cows . . . . & 55 & 92 & 38 & 31 & 68 & 29 & 219 \\
W. Mean . . . . & -17 & -23 & -45 & -1 & -4 & -16 & NS \\
\hline
\end{tabular}

(a) Somidobove ; (b) Sometribove ; (c) see tables 2, 4, 5 ; (d) BW change in BST cows - BW change in control cows ; (e) references $30,32-34,36,38-39,43$; NS = no significant change.

\section{TABLE 11}

Effect of dose and frequency of BST injections on body condition score (d).

Effet de la dose et de la fréquence des injections de BST sur la note d'état corporel (d).

\begin{tabular}{l|r|r|r|r|r|r|r}
\hline $\begin{array}{c}\text { Dose (mg) } \\
\text { Frequency (days) }\end{array}$ & $\begin{array}{c}10-15 \\
1\end{array}$ & $\begin{array}{c}20-27 \\
1\end{array}$ & $\begin{array}{c}31-50 \\
1\end{array}$ & $\begin{array}{c}320(\mathrm{a}) \\
28\end{array}$ & $\begin{array}{c}640(\mathrm{a}) \\
28\end{array}$ & $\begin{array}{c}960(\mathrm{a}) \\
28\end{array}$ & $\begin{array}{c}500(\mathrm{~b}) \\
14\end{array}$ \\
\hline Mean . . . . . & -1.0 & -0.8 & -1.7 & -0.1 & -0.2 & -0.4 & -0.5 \\
S.D. . . . . & 0.3 & 0.5 & - & - & - & - & 0.4 \\
N. cows . . . . & 15 & 95 & 7 & 9 & 22 & 7 & 297 \\
W. Mean . . . & -1.0 & -0.5 & -1.7 & -0.1 & -0.1 & -0.4 & -0.2 \\
\hline
\end{tabular}

(a) Somidobove; (b) Sometribove; (c) see tables 2, 4, 5 ; (d) $0-5$ scale ; (c) this trend was confirmed by McGuffey et al. (1988) and Meyer et al. (1988); (f) references 30, 36, 39, 40.

Body composition and body lipids have been measured using deuteriated water dilution technique in three BST experiments (table 12). In the two experiments exceding 6 months, body lipid deposition was 16 to $69 \mathrm{~kg}$ lower in BST treated cows whose milk production increased. Higher body fat mobilization (blood free fatty acids) was also observed. In another Somidobove experiment (McGuffey et al., 1988), subcutaneous fat depth was decreased. Theoretical calculation shows that a $1 \mathrm{Mcal} / \mathrm{d}$. decrease of energy balance (net energy) is equivalent to a $28 \mathrm{~kg}$ lipid deposition decrease over 38 weeks (assuming the same efficiency of metabolisable energy for milk secretion and body lipid deposition).

Increases in blood free fatty acids were also observed in some BST experiments (Rowe-Bechtel et al., 1988 ; Rémond et al., 1988), but not in others (Oldenbroek et 
TABLE 12

Effects of BST on body composition of dairy cows.

Effets de la BST sur la composition corporelle des vaches laitières.

\begin{tabular}{|c|c|c|c|c|c|c|}
\hline \multirow{2}{*}{ BST-Control } & \multicolumn{3}{|c|}{ Daily injections (a) } & \multicolumn{2}{|c|}{ Somidobove (b) } & \multirow{2}{*}{$\begin{array}{l}\text { Daily } \\
\text { injections (c) } \\
40 \mathrm{mg}\end{array}$} \\
\hline & $10 \mathrm{mg}$ & $21 \mathrm{mg}$ & $41 \mathrm{mg}$ & $\begin{array}{c}320 \mathrm{mg} \\
28 \mathrm{~d} .\end{array}$ & $\begin{array}{l}960 \mathrm{mg} \\
28 \mathrm{~d} .\end{array}$ & \\
\hline Milk yield $(\mathrm{kg} / \mathrm{d})$. & +3.5 & +7.6 & +7.0 & +0.2 & +2.2 & Increased \\
\hline Energy balance (Mcal/d) & -0.9 & -1.4 & -2.7 & +0.2 & -1.0 & Decreased \\
\hline Body weight change (kg) & -42 & -45 & -66 & +18 & -25 & +2 \\
\hline Body lipids change $(\mathrm{kg})(\mathrm{d})$. & -16 & -69 & -50 & +1 & -42 & -4 \\
\hline Body condition score change (e) & -1.2 & -1.6 & -1.7 & +0.2 & -0.2 & - \\
\hline Blood free fatty acids ( $\%$ over control) & +36 & +29 & +54 & +19 & +97 & - \\
\hline
\end{tabular}

(a) Soderholm et al., 1988 ; 20 cows, BST over 38 weeks (15 cows).

(b) Vérité and ChIlliard, unpublished : 21 cows, BST over 24 weeks (13 cows). Deuteriated water dilution technique was previously standardized on 20 slaughtered dairy cows (CHILliard and Robelin, 1983).

(c) Brown et al., 1988: 16 cows, BST over 7 weeks (9 cows).

(d) Estimated by deuteriated water dilution technique. (e) scale $0-5$.

al., 1987 ; Hutchison et al., 1986). Transient increases were observed during the first months of BST when the energy balance of the cows decreased, but not during the remainder of the lactation when DM intake increased above controls (LANZA et al., $1988 \mathrm{~b}, \mathrm{c})$.

Blood free fatty acids vary with feeding time. They can also change during the cycle between two BST injections (VérITÉ et al., 1988) as well as long chain fatty acid content of milk fat (FARries and ProfitTlich, 1987 ; Lynch et al., 1988 ; Vérité et al., 1988), indicating higher body fat mobilization immediately after each BST injection. BST can indeed increase the lipolytic response in cows with low energy balances (Sechen et al., 1988 and reviews by Vernon, 1986, and Chilliard, 1987, 1988).

Cyclic variations of body weight $( \pm 5-10 \mathrm{~kg}$ ) were observed between Sometribove injections (PhiPrs, 1987 ; Anderson et al., 1988), but not for DM intake (BAUMAN et $a l ., 1988)$. It is not known if this can reflect changes in gut or mammary contents, or in body composition.

\section{Feed efficiency}

Feed efficiency was increased 17 p. 100 (over control) by injecting daily $31-50 \mathrm{mg}$ of BST. The corresponding values were 8 p. 100 for Somidobove and 6 p. 100 for Sometribove (table 13).

Digestibility of the diet components, maintenance requirement and efficiency of metabolisable energy for milk secretion were not significantly increased in BST shortterm experiments (Tyrrell et al., 1982 ; EISEMANN et al., 1986), nor DM digestibility in long-term experiments (PeEl et al., 1985 ; Dhiman et al., 1988 ; Rémond et al., 1988). 
TABLE 13

Effects of BST on feed efficiency in dairy cows.

Effets de la BST sur l'efficacité alimentaire chez la vache laitière.

\begin{tabular}{|c|c|c|c|c|c|}
\hline Daily injections (mg/d.) & & 0 & $10-15$ & $20-27$ & $31-50$ \\
\hline FCM/DMI (a) & $\begin{array}{l}\text { W. Mean } \\
\text { N. Cows }\end{array}$ & $\begin{array}{r}1.31 \\
115\end{array}$ & $\begin{array}{r}1.46 \\
108\end{array}$ & $\begin{array}{r}1.47 \\
138\end{array}$ & $\begin{array}{r}1.53 \\
84\end{array}$ \\
\hline FCM/NEI (b) & $\begin{array}{l}\text { W. Mean } \\
\text { N. Cows }\end{array}$ & $\begin{array}{r}0.78 \\
60\end{array}$ & $\begin{array}{r}0.86 \\
49\end{array}$ & $\begin{array}{r}0.89 \\
80\end{array}$ & $\begin{array}{r}0.91 \\
41\end{array}$ \\
\hline Somidobove (mg/28 d.) & & 0 & 320 & 640 & 960 \\
\hline FCM/NEI (c) & $\begin{array}{l}\text { W. Mean } \\
\text { N. Cows }\end{array}$ & $\begin{array}{r}0.76 \\
77\end{array}$ & $\begin{array}{r}0.81 \\
68\end{array}$ & $\begin{array}{r}0.82 \\
77\end{array}$ & $\begin{array}{r}0.82 \\
77\end{array}$ \\
\hline Sometribove $(\mathrm{mg} / 14 \mathrm{~d})$. & & 0 & & & 500 \\
\hline FCM/NEI (d) & $\begin{array}{l}\text { W. Mean } \\
\text { N. Cows }\end{array}$ & $\begin{array}{r}0.78 \\
367\end{array}$ & & & $\begin{array}{r}0.83 \\
408\end{array}$ \\
\hline
\end{tabular}

(a) (Fat-corrected) milk/Dry matter intake. References $1,3,5-7,10-11,14-17$ in table 2.

(b) (Fat-corrected) milk/Net energy intake. References 1, 3, 10-11, 14-15, 17 in table 2.

(c) References 23-26 in table 4 - (d) References 30-38, 39-42 in table 5.

Increase in feed efficiency resulted 1/ from dilution of maintenance requirement in the total requirement, due to milk yield increase, and $2 /$ from lower use of nutrients for body tissue deposition, relatively to milk secretion. These two reasons can explain the higher increase of feed efficiency with daily-injection experiments (table 13), since milk response and energy balance decrease were more pronounced than with prolonged release preparations.

\section{E. Interactions of BST response with animal and management factors}

\section{Parity}

Lower responses in heifers than in multiparous cows have been reported (MARSH et al., 1987 ; Huber et al., 1988 ; Rowe-Bechtel et al., 1988 ; Tessmann et al., 1988 ; VÉrité et al., 1988 ; WhITAKER et al., 1988). However there was no difference (or higher responses in heifers) in other studies (Chalupa et al., 1988 ; HARD et al., 1988 ; LAmb et al., 1988 ; Pell et al., 1988 ; RÉmond et al., 1988 ; SAmuels et al., 1988).

\section{Milk production potential}

Most authors observed great individual variations in the response $(\mathrm{kg} / \mathrm{d}$.) to BST. It is not known if this variability is repeatable from one lactation to the next. It was not related to individual variations in milk potential (LANZA et al., 1988 a ; Sullivan et 
al., 1988) nor to predicted differences of the sires (MCDANIEL and HAYEs, 1988). Negative relationships with individual milk potential were however recorded by LEICHT et al. (1987) and OldenBroek et al. (1987). There was no interassay relationship between milk production of control groups and response to BST in data from tables 2, 4 and 5 ,

These observations on parity and milk potential effects show that percentage milk response to BST (relative to control) decreases when milk yield increases.

\section{Lactation stage and consecutive lactations}

Response to BST $(\mathrm{kg} / \mathrm{d})$ did not seem to be dependent on the stage of lactation (after the first month) at which treatment began (Meyer et al., 1988). For a given initial stage, the persistency of the response during the remainder of the lactation was rather variable, but tended often to decrease (FurNiss et al, 1988 ; HUBER et al., 1988 ; Lossouarn, 1988 ; PhIPPS, 1987 ; Peel et al., 1988, table 9 ; RÉmond et al., 1988 ; VÉRITÉ et al., 1988), perhaps in relation to management factors, pregnancy stage, and the physiological need of the cow to maintain body reserves.

BST use during one lactation did not appear to influence yield at the beginning of the subsequent lactation (PHIPPS, 1987). The percentage of twin calves was increased in BST cows during 2 European experiments (Phipps, 1987 ; Rijpkema et al., 1987). These observations need to be confirmed. On the other hand, milk responses to BST during a second consecutive lactation were of the same magnitude as during the first (ANNEXSTAD et al., 1987 ; HEMKEN et al., 1988 ; EPPARD et al., 1988).

\section{Nutrition}

During short-term experiments, milk response to BST was not increased by postruminal infusions of glucose and casein (PEel et al., 1982), nor by the addition of sodium bicarbonate or branched-chain volatile fatty acids to the diet (KIK and CoOK, 1986 ; Chalupa et al., 1984, 1985). Although a positive interaction was observed between BST and calcium soaps of fatty acids (SCHNEIDER et al., 1987) it was not the case with a hydrolysed blend of fats (LougH et al., 1988).

During long-term experiments there was no clear effect of concentrate level or cereal nature (table 14), except in Tessmann et al. (1988). In this experiment, cows receiving low concentrate diet were in lower body condition at the end of BST treatment, and they had a lower persistency during the next BST lactation.

An effect of protein content and degradability was observed by McGuFFEY et al. (1988), but untreated control cows only received the low protein diet. The lower response in low protein diet was due to a lower persistency of the response during BST treatment, and the authors suggested it could be due to exhaustion of body protein reserves. Increasing the percentage of undegradable protein did not however increase the response to BST to the same extent in cows of lower milk potential (VÉRITÉ et al., 1988).

Data from tables 2, 4 and 5 have been pooled according to feeding diets (table 15). The significance of the different means is poor, since all other experimental conditions were not comparable between assays. It seems however that higher responses could be obtained with several complete mixed rations of different energy content, given according to milk yield. Responses were lower in European feeding conditions. During the 3 winter flat rate concentrate feeding experiments, there was a lower body weight gain in 


\section{TABLE 14}

Comparisons of different diets in long-term BST experiments.

Comparaisons de régimes dans les essais à long terme avec la BST.

\begin{tabular}{|c|c|c|c|c|c|}
\hline \multirow{2}{*}{ Reference } & \multirow{2}{*}{$\begin{array}{l}\text { Dose } \\
\text { (mg) }\end{array}$} & \multirow{2}{*}{$\begin{array}{l}\text { N. Cows } \\
\text { per group }\end{array}$} & \multirow{2}{*}{$\begin{array}{l}\text { Weeks } \\
\text { of BST }\end{array}$} & \multicolumn{2}{|c|}{ Milk response $(\mathrm{kg} / \mathrm{d})$} \\
\hline & & & & $\begin{array}{l}\text { " Low » Diet } \\
\text { (LD) }\end{array}$ & " $\underset{\text { (HD) }}{\text { High } » ~ D i e t ~}$ \\
\hline A & $25 / \mathrm{d}$ & 10 & 37 & $4.6^{*}$ & 4.9 \\
\hline B & $21 / \mathrm{d}$ & 6 & 30 & 7.8 & 7.8 \\
\hline $\mathrm{C}$ & $21 / \mathrm{d}$ & 10 & 38 & 4.5 & 4.5 \\
\hline D & $640 / 28 \mathrm{~d}$. & 8 & 16 & 2.4 & 5.3 \\
\hline $\mathrm{E}$ & $500 / 14 \mathrm{~d}$ & 12 & 12 & 2.7 & 2.7 \\
\hline F & $21 / \mathrm{d}$ & 16 & 31 & 4.0 & 6.1 \\
\hline
\end{tabular}

A - Thomas et al., 1987 - LD = flat rate concentrate $\left(9 \mathrm{~kg} / \mathrm{d}\right.$.) over 24 weeks, then pasture. ${ }^{*}$ Lower weight gain over 24 weeks - HD $=$ complete mixed rations.

B - EISENBEIz et al., 1988 a. Corn vs. barley concentrate.

C - HemKen et al., 1988. $40 \%$ vs. $60 \%$ concentrate.

D - McGuffey et al., $1988 ; \mathrm{LD}=14 \%$ protein, $30 \%$ undegradable protein - HD = $17 \%$ protein, $40 \%$ undegradable protein.

E - RÉMOND et al., 1988. $2.5 \mathrm{vs} 5.4 \mathrm{~kg} / \mathrm{d}$ concentrate (corn silage ad libitum, no difference in total DM intake). F - Tessmann et al., $1988 ; 12-32 \%$ vs $32-52 \%$ concentrate (alfalfa silage diet).

\section{TABLE 15}

Summary of BST production responses according to feeding diets.

Récapitulatif des réponses en lait à la BST en fonction des régimes alimentaires.

\begin{tabular}{|c|c|c|c|c|}
\hline Diet & $1 \mathrm{CMD}$ & 2-4 CMD & $F+C$ & Pasture \\
\hline $\begin{array}{l}\text { Daily injections } \\
(20-27 \mathrm{mg} / \mathrm{d} .)\end{array}$ & $\begin{array}{c}4.7( \pm 1.8) \\
\mathrm{n}=11(\mathrm{a}) \\
\mathrm{E}=1\end{array}$ & $\begin{array}{c}6.6( \pm 2.2) \\
\mathrm{n}=7(\mathrm{~b})\end{array}$ & & \\
\hline $\begin{array}{l}\text { Somidobove or } \\
\text { Sometribove }\end{array}$ & & $\begin{array}{c}5.3( \pm 2.0) \\
\mathrm{n}=10(\mathrm{c}) \\
\mathrm{E}=2\end{array}$ & 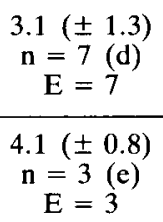 & $\begin{array}{c}2.5( \pm 1.8) \\
\mathrm{n}=8(\mathrm{f}) \\
\mathrm{E}=6\end{array}$ \\
\hline
\end{tabular}

$1 \mathrm{CMD}=$ one complete mixed ration.

2-4 CMD $=2-4$ complete mixed rations of different energent content, according to milk yields.

$\mathbf{F}+\mathbf{C}=($ ad libitum forages $)+$ (concentrates) $-\mathbf{E}=$ European experiments.

(a) References $2-5,8,14-18$ (table 2) - (b) References $1,7,10-11,13,19-20$ (table 2) - (c) References 30-34 36-37, 40, 42 (table 5) - (d) Concentrates according to milk yield - References 26-27, 29, 35, 39, 41, 43 (table 4 and 5) - (e) Flat rate concentrates - ThOMAs et al., 1987 ; FURNISs et al., 1988 ; WhitaKer et al., 1988 - (f) References 27-29 (table 4), 39, 43 (table 5), Brumby and Hancock, 1955; PeEl et al., 1985, 1988 ; Furniss et al., 1988 . 
BST cows, but milk response was rather high. The low responses at pasture (table 16) could be due to higher lactation-pregnancy stages (VÉRITÉ et al., 1988) or to low quality pasture during drought periods (Lossouarn, 1988).

\section{Environmental conditions}

Mollett et al. (1986) observed low response $(+2$ to +4 p. 100) to $27-40 \mathrm{mg}$ $\mathrm{BST} / \mathrm{d}$. over 27 weeks in 18 cows, and hypothesized that hot and humid climatic conditions may have affected treatment response. However Collier and JoHnson (1988) summarized data from short- and long-term experiments in cold and hot conditions, and concluded that BST response was not impaired if feeding and management conditions were adequate.

TABLE 16

Milk response $(\mathrm{kg} / \mathrm{d})$ to BST in Europe according to season* and feeding conditions.

Réponse en lait à la BST dans les essais européens en fonction des conditions saisonnières * et alimentaires.

\begin{tabular}{|c|c|c|c|}
\hline \multirow{2}{*}{$\begin{array}{l}\text { Season } \\
\text { Diet }\end{array}$} & \multirow{2}{*}{$\begin{array}{c}\text { Winter } \\
\text { Silage }+ \text { concentrate }\end{array}$} & \multicolumn{2}{|c|}{$\begin{array}{l}\text { Spring and/or summer } \\
\text { Pasture (+ Concentrate) }\end{array}$} \\
\hline & & & Pasture quality \\
\hline $\begin{array}{l}\text { FuRnISS } \text { et al., } 1988 \ldots \ldots \ldots \\
\text { PEEL, } 1988 \ldots \ldots \ldots \ldots\end{array}$ & 4.8 & 4.5 & Good \\
\hline LosSOUARN, 1988 . & 5.6 & 2.8 & Low \\
\hline PARRASSIN and VIGNON, 1988 & 1.3 & 1.3 & Medium \\
\hline RÉMOND et al., $1988 \quad \ldots \ldots$ & 2.7 & 2.0 & Medium \\
\hline VÉRITÉ et al., 1988 & 2.0 & 0.3 & Good \\
\hline
\end{tabular}

* Including lactation stage or treatment duration effects.

\section{Conclusions}

BST has a great potential for increasing cow milk yield (about $+5 \mathrm{~kg} / \mathrm{d}$ or $+1000 \mathrm{~kg}$ per lactation for a 200 -day treatment with slow release preparations). However, responses can be much lower (1-4 kg/d), especially in European management conditions. So, percentage increase of lactation yield can vary from less than 5 to more than 25 p. 100, depending on milk production level of untreated cows, on treatment duration and on mean response to BST.

BST decreases energy balance and body reserve gain during the first 3 months of treatment. This leads to increased delay in conception and inter-calving interval, as in higher yielding untreated cows. Cycling of milk composition between injections will lead to increased milk recording and quality control frequencies, but this should be avoided by improving slow release delivery systems in the future. 
Increase in feed efficiency (FCM/NEI) results simply from increased milk yield (decreasing the part of maintenance in total needs) and from decreased body tissue gain. If body gain over the period is similar to that of control cows, increase of feed efficiency will be of about $6 \mathrm{p}$. 100 for a $4 \mathrm{~kg} / \mathrm{d}$ increase in milk yield.

Heifer response was lower in some experiments, but not in others. BST responses were highly variable between adult cows, but not related to individual milk potential. New knowledge is needed to explain this and to improve strategies for BST use. Feeding management is important for milk response to BST, as well as for improving body condition and reproductive performances of the BST treated cows. Present data indicate a lower response $(2.5 \pm 1.8 \mathrm{~kg} / \mathrm{d})$ to BST in pasture European conditions.

Reçu en octobre 1988.

Accepté en Décembre 1988.

\section{Aknowledgments}

I thank Monsanto and Elanco Companies, and particularly C.J. Peel, for access to unpublished data, and Y. Fournier and L. Souchet for typing the manuscript.

\section{Résumé}

Effets à long terme de la somatotropine bovine recombinée (hormone de croissance) sur les performances des vaches laitières *

Les effets à long terme (18-32 semaines) de la somatotropine bovine (BST) injectée quotidiennement (650 vaches, 20 essais) ou sous forme « retard " (790 vaches, injections mensuelles ou bimensuelles, 23 essais) sont analysés. Des injections journalières de 10-15, 20-27 ou 31-50 mg de BST augmentent la production laitière de $3,9-5,2$ ou $5,6 \mathrm{~kg} / \mathrm{j}$, respectivement. Le produit Somidobove $(320,640$ ou $960 \mathrm{mg}$ de BST tous les 28 jours) augmente la production laitière de $2,2-3,1$ ou $4,2 \mathrm{~kg} / \mathrm{j}$, et le produit Sometribove ( $500 \mathrm{mg}$ de BST tous les 14 jours) de $4,4 \mathrm{~kg} / \mathrm{j}$. La composition moyenne du lait n'est pas modifiée, mais la production laitière et les taux butyreux et protéique fluctuent entre les injections dans le cas des formes "retard " de la BST.

L'ingestion de matière sèche s'accroît de $1,5-1,7 \mathrm{~kg} / \mathrm{j}$ pour les doses élevées de BST dans les essais de longue durée (32 semaines), et de $0,8 \mathrm{~kg} / \mathrm{j}$ dans les essais de 18 semaines. Le bilan énergétique et la note d'état corporel diminuent pendant les 3 premiers mois de traitement en raison d'un temps de latence avant que l'ingestion de la ration n'augmente. Dans deux essais, le dépôt de lipides corporels a été fortement réduit par la BST.

L'efficacité alimentaire augmente de 6 à 17 p. 100 en raison de la dilution du besoin d'entretien dans le besoin total (ce qui explique $6 \mathrm{p}$. 100 d'augmentation), et en raison de la diminution du gain de poids des vaches (pouvant expliquer $10 \mathrm{p} .100$ de cette augmentation). Il n'y a pas d'interactions claires entre la réponse à la BST et l'âge, ou le potentiel laitier des vaches, mais une tendance montrant que la réponse diminue après plusieurs mois de traitement. Les rations complètes en mélange, à hautes teneurs en énergie et en protéines, permettent une réponse en lait plus élevée, mais la variabilité entre vaches et entre essais est très élevée. Les réponses sont plus faibles $(2,5 \pm 1,8 \mathrm{~kg}$ de lait par jour) au pâturage dans les conditions européennes.

\footnotetext{
* La traduction française de cet article est disponible sur demande à l'auteur.
} 


\section{References}

Aguilar A.A., Jordan D.C., Olson J.D., Bailey C., Hartnell G., 1988. A short-study evaluating the galactopoietic effects of the administration of Sometribove (recombinant methionyl bovine somatotropin) in high producing dairy cows milked three times per day. $J$. Dairy Sci., 71 (suppl. 1), 208 (Abstr.).

Anderson M.J., Lamb R.C., Arambel M.J., Boman R.L., Hard D.L., Kung L., 1988. Evaluation of a prolonged release system of sometribove, USAN (recombinant methionyl bovine somatotropin) on feed intake, body weight, efficiency and energy balance of lactating cows. J. Dairy Sci., 71 (suppl. 1), 208 (Abstr.).

Annexstad R.J., Otterby D.E., Linn J.G., Hansen W.P., Soderholm C.G., Eggert R.G., 1987. Responses of cows to daily injections of recombinant bovine somatotropin (BST) during a second consecutive lactation. J. Dairy Sci., 70 (suppl. 1), 176 (Abstr.).

Baird L.S., Hemken R.W., Harmon R.J., Eggert R.G., 1986. Response of lactating dairy cows to recombinant bovine growth hormone (rbGH). J. Dairy Sci., 69 (suppl. 1), 118 (Abstr.).

Barbano D.M., Lynch J.M., Bauman D.E., Hartnell G.F., 1988. Influence of sometribove (recombinant methionyl bovine somatotropin) on general milk composition. J. Dairy Sci., 71 (suppl. 1), 101 (Abstr.).

Bauman D.E., DeGeeter M.J., Peel C.J., Lanza G.M., Gorewit R.C., Hammond R.W., 1982. Effects of recombinantly derived bovine growth hormone (bGH) on lactational performance of high yielding dairy cows. J. Dairy Sci., 65 (suppl. 1), 121 (Abstr.).

Bauman D.E., Eppard P.J., DeGeeter M.J., Lanza G.M., 1985. Responses of high-producing dairy cows to long-term treatment with pituitary somatotropin and recombinant somatotropin. J. Dairy Sci., 68, 1352-1362.

Bauman D.E., Hard D.L., Crooker B.A., Erb H.N., Sandles L.D., 1988. Lactational performance of dairy cows treated with a prolonged-release formulation of methionyl bovine somatotropin (sometribove), J. Dairy Sci., 71 (suppl. 1), 205 (Abstr.).

Brown D.L., Taylor S.J., De Peters E.J., Baldwin R.L., 1988. Influence of sometribove (a methionyl bovine somatotropin) on the body composition of lactating Holstein cattle. J. Dairy Sci., 71 (suppl. 1), 125 (Abstr.).

Brumby P.J., Hancock J., 1955. The galactopoietic role of growth hormone in dairy cattle. J. Sci. Technol., 36, 417-436.

Burton J.H., McBride B.W., Bateman K., MacLeod G.K., Eggert R.G., 1987. Recombinant bovine somatotropin : effects on production and reproduction in lactating cows. J. Dairy Sci., 70 (suppl. 1), 175 (Abstr.).

Chalupa W., Baird L., Soderholm C., Palmquist D.L., Hemken R., Otterby D., Annexstad R., Vecchiarelli B., Harmon R., Sinha A., Linn J., Hansen W., Ehle F., Schneider P., EGGERT R., 1987 b. Responses of dairy cows to somatotropin. J. Dairy Sci., 70 (suppl. 1), 176 (Abstr.).

Chalupa W., Galligan D.T., 1988. Nutritional implications of somatotropin for lactating cows. J. Dairy Sci., 71 (suppl. 1), 123 (Abstr.).

Chalupa W., Hausman B., Kronfeld D.S., Kensinger R.S., McCarthy R.D., Rock D.W., 1984 a. Responses of lactating cows to exogenous growth hormone and dietary sodium bicarbonate. I. Production. J. Dairy Sci., 67 (suppl. 1), 107 (Abstr.).

Chalupa W., Kutches A., Swager D., Lehendauer T., Vecchiarelli B., Shaver R., Robb E., 1988. Responses of cows in a commercial dairy to somatotropin. J. Dairy Sci., 71 (suppl. 1), 210 (Abstr.).

Chalupa W., Marsh W.E., Galligan D.T., 1987 a. Bovine somatotropin : lactational responses and impacts on feeding programs. Proc. Maryland. Nutr. Conf. Feed Manuf., 48-57.

Chalupa W., Vecchiarelli B., Schneider P., Eggert R.G., 1986. Long-term responses of lactating cows to daily injection of recombinant somatotropin. J. Dairy Sci., 69 (suppl. 1), 151 (Abstr.).

Chilliard Y., 1987. Revue bibliographique : Variations quantitatives et métabolisme des lipides dans les tissus adipeux et le foie au cours du cycle gestation-lactation. $2^{\mathrm{e}}$ partie : chez la brebis et la vache. Reprod. Nutr. Dévelop., 27, 327-398. 
Chilliard Y., 1988. Rôles et mécanismes d'action de la somatotropine (hormone de croissance) chez le ruminant en lactation. Reprod. Nutr. Dévelop., 28, 39-59.

Chilliard Y., Robelin J., 1983. Mobilization of body proteins by early lactating cows measured by slaughter and D20 dilution techniques. IVth. Int. Symp. Protein metabolism and nutrition (Clermont-Ferrand), EAAP - Publ. No 31, Vol. II, 195-198 (INRA Publ.).

Collier R.J., Johnson H.D., 1988. Bovine somatotropin - Mechanism of action and effects under differing environments. (Ed. Monsanto technical Symposium, Fresno, California, U.S.A.), p. 11-19.

Dhiman T.R., Kleinmans J., Radloff H.D., Tessmann N.J., Satter L.D., 1988. Effect of recombinant bovine somatotropin on feed intake, dry matter digestibility and blood constituents in lactating dairy cows. J. Dairy Sci., 71 (suppl. 1), 121 (Abstr.).

Eisemann J.H., Tyrrell H.F., Hammond A.C., Reynolds P.J., Bauman D.E., Haaland G.L., McMurTRY J.P., VARGa G.A., 1986. Effect of bovine growth hormone administration on metabolism of growing hereford heifers : dietary digestibility, energy and nitrogen balance. J. Nutr., 116, 157-163.

Eisenbeisz W.A., CASPER D.P., Schingoethe D.J., Ludens F.C., 1988 a. Lactational evaluation of recombinant bovine somatotropin with corn and barley diets : response to diets. J. Dairy Sci., 71 (suppl. 1), 122 (Abstr.).

Eisenbeisz W.A., Casper D.P., Schingoethe D.J., Ludens F.C., Shaver R.D., 1988 b. Lactational evaluation of recombinant bovine somatotropin with corn and barley diets : response to somatotropin. J. Dairy Sci., 71 (suppl. 1), 123 (Abstr.).

Elvinger F., Head H.H., Wilcox C.J., Natzke R.P., Eggert R.G., 1988. Effects of administration of bovine somatotropin on milk yield and composition. J. Dairy Sci., 71, 1515-1525.

Eppard P.J., Bauman D.E., McCutcheon S.N., 1985. Effect of dose of bovine growth hormone on lactation of dairy cows. J. Dairy Sci., 68, 1109-1115.

Eppard P.J., lanza G.M., Hudson S., Cole W.J., Hintz R.L., White T.C., Ribelin W.E., Hammond B.G., Bussen S.C., Leak R.K., Metzger L.E., 1988. Response of lactating dairy cows to multiple injections of sometribove, USAN (recombinant methionyl bovine somatotropin) in a prolonged release system. Part. I. Production response. J. Dairy Sci., 71 (suppl. 1), 184 (Abstr.).

Farries E., Profittlich C., 1987. The influence of applicated bovine somatotropin on some metabolic criteria in dairy cows. 38th Ann. Meeting Europ. Ass. Anim. Prod. (Lisbon, Portugal), p. 432.

Faverdin P., Hoden A., Coulon J.B., 1987. Recommandations alimentaires pour les vaches laitières. Bull. Tech. C.R.Z.V. Theix, INRA, 70, 133-152.

Furniss S.J., Stroud A.J., Brown A.C.G., SMith G., 1988. Milk production, feed intakes and weight change of autumn calving, flat rate fed dairy cows given two weekly injections of recombinantly derived bovine somatotropin (BST). Proc. Brit. Soc. Anim. Prod., Winter Meeting, Paper $\mathrm{N}^{\mathbf{0}} 1$.

Gravert M.O., Pabst K., Wollny C., 1988. Quoted by Peel et al., 1988.

Hard D.L., Cole W.J., Franson S.E., Samuels W.A., Bauman D.E., Erb H.N., Huber J.T., LAMB R.C., 1988. Effect of long term sometribove, USAN (recombinant methionyl bovine somatotropin), treatment in a prolonged release system on milk yield, animal health and reproductive performance-pooled across four sites. J. Dairy Sci., 71 (suppl. 1), 210 (Abstr.).

HART I.C., 1988. Altering the efficiency of milk production of dairy cows with somatotropin. In : Garnsworthy P.C. ed. Nutrition and lactation in the dairy cow. Butterworths, London, 232247.

Hemken R.W., Harmon R.J., Silvia W.J., Heersche G., Eggert R.G., 1988. Response of lactating dairy cows to a second year of recombinant bovine somatotropin (BST) when fed two energy concentrations. J. Dairy Sci., 71 (suppl. 1), 122 (Abstr.).

HUBER J.T., 1987. The production response of BST : feed additives, heat stress and injection intervals. In " National invitational workshop on bovine somatotropin ». (Saint-Louis, U.S.A.), $57-60$.

Huber J.T., Willman S., Marcus K., Theurer C.B., 1988. Effect of sometribove (SB). USAN (recombinant methionyl bovine somatotropin) injected in lactating cows at 14-d intervals on milk yields, milk composition and health. J. Dairy Sci., 71 (suppl. 1), 207 (Abstr.). 
Hutchison C.F., Tombinson J.E., McGee W.H., 1986. The effects of exogenous recombinant or pituitary extracted bovine growth hormone on performance of dairy cows. J. Dairy Sci., 69 (suppl. 1), 152 (Abstr.).

Jenny B.F., Ellers J.E., Tingle R.B., Moore M., Grimes L.W., Rock D.W., 1988. Responses of dairy cows to recombinant bovine somatotropin in a sustained release vehicle. $J$. Dairy Sci., 71 (suppl. 1), 209 (Abstr.).

Journet M., Chilliard Y., 1985. Influence de l'alimentation sur la composition du lait. I. Taux butyreux : facteurs généraux. Bull. Tech. C.R.Z.V. Theix, INRA, 60, 13-23.

KIK N., Cook R.M., 1986. Effects of bovine somatotropin and IsoPlus on milk production. J. Dairy Sci., 69 (suppl. 1), 158 (Abstr.).

lamb R.C., Anderson M.J., Henderson S.L., Call J.W., Callan R.J., Hard D.L., Kung L., 1988. Production response of Holstein cows to sometribove USAN (recombinant methionyl bovine somatotropin) in a prolonged release system for one lactation. J. Dairy Sci., 71 (suppl. 1), 208 (Abstr.).

Lanza G.M., Baile C.A., Collier R.J., 1988 a. Development and potential of BST. Nutr. Institute, Nat. Feeds. Ingr. Ass. (U.S.A.) (14 p.).

lanza G.M., Eppard P.J., Miller M.A., Franson S.E., Ganguli S., Hintz R.L., Hammond B.G., Bussen S.C., Leak R.K., Metzger L.E., 1988 b. Response of lactating dairy cows to multiple injections of sometribove, USAN (recombinant methionyl bovine somatotropin) in a prolonged release system. Part III. Changes in circulating analytes. J. Dairy Sci., 71 (suppl. 1), 184 (Abstr.).

lanza G.M., White T.C., Dyer S.E., Hudson S., Franson S.E., Hintz R.L., Duque J.A., Bussen S.C., Leak R.K., Metzger L.E., $1988 \mathrm{c}$. Response of lactating dairy cows to intramuscular or subcutaneous injection of sometribove, USAN (recombinant methionyl bovine somatotropin) in a 14-day prolonged release system. Part II. Changes in circulating analytes. J. Dairy Sci., 71 (suppl. 1), 195 (Abstr.).

Leitch H.W., Burnside E.B., Macleod G.K., McBride B.W., Kennedy B.W., Wilton J.W., 1987. Genetic and phenotypic effects of administration of recombinant bovine somatotropin to holstein cows. J. Dairy Sci., 70 (suppl. 1), 128 (Abstr.).

Lossouarn J., 1988. Etude d'une formulation retard de zinc-methionyl bovine somatotropine pour la production laitière. Compte rendu d'essai. I.N.A. Paris-Grignon-Monsanto-France.

Lough D.S., Muller L.D., Kensinger R.S., Sweeney T.F., Griel Jr L.C., 1988. Effect of added dietary fat and bovine somatotropin on the performance and metabolism of lactating dairy cows. J. Dairy Sci., 71, 1161-1169.

Lynch J.M., Barbano D.M., Bauman D.E., Hartnell G.F., 1988. Influence of sometribove (recombinant methionyl bovine somatotropin) on the protein and fatty acid composition of milk. J. Dairy Sci., 71 (suppl. 1), 100 (Abstr.).

Marsh W.E., Galligan D.T., Chalupa W., 1987. Making economic sense of bovine somatotropin use in individual dairy herds. In "Nutrient partitioning ", (Ed. Am. Cyanamid Techn. Symp., California, U.S.A.), p. 59-79.

Meyer R.M., McGuffey R.K., Basson R.P., Rakes A.H., Harrison J.H., Emery R.S., Muller L.D., Buock E., 1988. The effect of somidobove sustained release injection on the lactation performance of dairy cattle. J. Dairy Sci., 71 (suppl. 1), 207 (Abstr.).

Mollett T.A., DeGeeter M.J., Belyea R.L., Youngquist R.A., Lanza G.M., 1986. Biosynthetic or pituitary extracted bovine growth hormone induced galactopoiesis in dairy cows. J. Dairy Sci., 69 (suppl. 1), 118 (Abstr.).

MunNeKe R.L., Sommerfeldt J.L., Ludens E.A., 1988. Lactational responses of dairy cows to recombinant bovine somatotropin. J. Dairy Sci., 71 (suppl. 1), 206 (Abstr.).

McDaniel B.T., Hayes P.W., 1988. Absence of interaction of merit for milk with recombinant bovine somatotropin. J. Dairy Sci., 71 (suppl. 1), 240 (Abstr.).

McGuffey R.K., Green H.B., Basson R.P., 1987 b. Performance of Holsteins given somatotropin in a sustained delivery vehicle. Effect of dose and frequency of administration. J. Dairy Sci., 71 (suppl. 1), 177 (Abstr.).

McGuffey R.K., Green H.B., Basson R.P., 1988. Protein nutrition of the somatotropin-treated cow in early lactation. J. Dairy Sci., 71 (suppl. 1), 120 (Abstr.). 
McGuffey R.K., Green H.B., Ferguson T.H., 1987 a. Lactation performance of dairy cows receiving recombinant bovine somatotropin by daily injection or in a sustained release vehicle. J. Dairy Sci., 70 (suppl. 1), 176 (Abstr.).

Nytes A.J., CомBS D.K., SHOoK G.E., 1988. Efficacy of recombinant bovine somatotropin injected at three dosage levels in lactating dairy cows of different genetic potentials. J. Dairy Sci., 71 (suppl. 1), 123 (Abstr.).

Oldenbroek J.K., Garssen G.J., Forbes A.B., Jonker L.J., 1987. The effect of treatment of dairy cows of different breeds with recombinantly derived bovine somatotropin in a sustained delivery vehicle. 38th Ann. Meeting Europ. Ass. Anim. Prod. (Lisbon, Portugal) (32 p.).

PALMQUisT D.L., 1988. Response of high-producing cows given daily injections of recombinant bovine somatotropin from D 30-296 of lactation. J. Dairy Sci., 71 (suppl. 1), 206 (Abstr.).

PARRASSIN P.R., VIGNON B., 1988. Effects of somatotropin on milk production and composition in Montbéliarde cows - Study report. (INRA-Mirecourt-E.N.S.A.I.A.-Nancy-Elanco-France).

PeEl C.J., 1988. Bovine somatotropin (BST) - A review of efficacy and mechanism of action in dairy cows. (To be published).

Peel C.J., Bauman D.E., 1987. Somatotropin and lactation. J. Dairy Sci., 70, 474-486.

Peel C.J., Eppard P.J., Hard D.L., 1988. Evaluation of sometribove (methionyl bovine somatotropin) in toxicology and clinical trials in Europe and the United States. Proc. Int. Symp. on «Biotechnology in growth regulation" (18-20 September 1988, Babraham, Cambridge, U.K.) (In press).

Peel C.J., Fronk T.J., Bauman D.E., Gorewit R.C., 1982. Lactational response to exogenous growth hormone and abomasal infusion of a glucose-sodium caseinate mixture in high yielding dairy cows. J. Nutr., 112, 1770-1778.

Peel C.J., Sandles L.D., Quelch K.J., Herington A.C., 1985. The effects of long-term administration of bovine growth hormone on the lactational performance of identical-twin dairy cows. Anim. Prod., 41, 135-142.

Pell A.N., Tsang D.S., Huyler M.T., Howlett B.A., Kunkel J., 1988. Responses of Jersey cows to treatment with sometribove, USAN (recombinant methionyl bovine somatotropin) in a prolonged release system. J. Dairy Sci., 71 (suppl. 1), 206 (Abstr.).

Phipps R.H., 1987. The use of prolonged release bovine somatotropin in milk production. Int. Dairy Fed. Congr. (Helsinki, Finland) (23 p.).

RÉmoND B., 1985. Influence de l'alimentation sur la composition du lait de vache-2. Taux protéique : facteurs généraux. Bull. Tech. C.R.Z.V. Theix, INRA, 62, 53-67.

Rémond B., Chilliard Y., Cisse M., 1988. Effects of somatotropin (sometribove) on feed intake, performances and metabolism of dairy cows fed two levels of concentrates. Study report. (INRA-Theix-Monsanto-France).

RiJpkema Y.S., Peel C.J., 1988. Quoted by Peel et al., 1988.

Rujpema Y.S., Reeuwijk L.V., Peel C.J., Mol E., 1987. Responses of dairy cows to long-term treatment with somatotropin. 38th Ann. Meeting Europ. Ass. Anim. Prod. (Lisbon, Portugal). p. 428.

Rowe-Bechtel C.L., Muller L.D., Deaver D.R., Griel L.C., 1988. Administration of recombinant bovine somatotropin (rbSt) to lactating dairy cows beginning at 35 and 70 days postpartum. I. Production response. J. Dairy Sci., 71 (suppl. 1), 166 (Abstr.).

Samuels W.A., Hard D.L., Hintz R.L., Olsson P.K., Cole W.J., Hartnell G.F., 1988. Long term evaluation of sometribove, USAN (recombinant methionyl bovine somatotropin) treatment in a prolonged release system for lactating cows. J. Dairy Sci., 71 (suppl. 1), 209 (Abstr.).

Schneider P.L., Vecchiarelli B., Chalupa W., 1987. Bovine somatotropin and ruminally inert fat in early lactation. J. Dairy Sci., 70 (suppl. 1), 177 (Abstr.).

Sechen S.J., Dunshea F.R., Bauman D.E., 1988. Mechanism of bovine somatotropin (bST) in lactating cows : effect on response to homeostatic signals (epinephrine and insulin). J. Dairy Sci., 71 (suppl. 1), 168 (Abstr.).

Soderholm C.G., Otterby D.E., Linn J.G., Ehle F.R., Wheaton J.E., Hansen W.P., AnnexSTAD R.J., 1988. Effects of recombinant bovine somatotropin on milk production, body composition, and physiological parameters. J. Dairy Sci., 71, 355-365. 
Sullivan J.T., Taylor R.B., Huber J.T., Franson S.E., Hoffman R.G., Hard D.L., 1988. Relationship of production level and days postpartum to response of cows to sometribove, USAN (recombinant methionyl bovine somatotropin). J. Dairy Sci., 71 (suppl. 1), 207 (Abstr.).

Tessmann N.J., Kleinmans J., Dhiman T.R., Radloff H.D., Satter L.D., 1988. Effect of dietary forage : grain ratio on response of lactating dairy cows to recombinant bovine somatotropin. J. Dairy Sci., 71 (suppl. 1), 121 (Abstr.).

Thomas C., Johnsson I.D., Fisher W.J., Bloomfield G.A., Morant S.V., Wilkinson J.M., 1987. Effect of somatotropin on milk production, reproduction and health of dairy cows. J. Dairy Sci., 70 (suppl. 1), 175 (Abstr.).

Tyrrell H.F., Brown A.C., Reynolds P.J., Haaland G.L., Peel C.J., Bauman D.E., SteinHOUR W.C., 1982. Effect of growth hormone on utilization of energy by lactating Holstein cows. In Ekern A., Sundstol F., "Energy metabolism of farm animals ». E.E.A.P. Publ. $\mathrm{N}^{\circ} 29,46-47$.

Vedeau F., Schockmel L.R., 1988. Quoted by Peel et al., 1988.

Vérité R., Rulquin H., Faverdin P., 1988. Effects of slow released somatotropin on dairy cow performances. Proc. C.E.C. Seminar on "Use of somatotropin in Livestock production" (Bruxelles, 27-29 September 1988) (in press).

VERNON R.G., 1986. The response of tissues to hormones and the partition of nutrients during lactation. Hannah Res. Inst., Rep. 1985, 115-121.

Vignon B., LAURent J.F., Wallet P., 1988. Effects of somatotropin on milk production and composition in cows at pasture - Study report. (E.N.S.A.I.A.-INRA-Nancy-Elanco-France).

WEST J.W., Johnson J.C. Jr., BondaRi K., 1988. The effect of bovine somatotropin on productivity and physiologic responses of lactating Holstein and Jersey cows. J. Dairy Sci., 71 (suppl. 1), 209 (Abstr.).

Whitaker D.A., Smith E.J., Kelly J.M., Hodgson-Jones L.S., 1988. Health, welfare and fertility implications of the use of bovine somatotropin in dairy cattle. Vet. Rec., 122, 503-505.

White T.C., Lanza G.M., Dyer S.E., Hudson S., Franson S.E., Hintz R.L., Duque J.A.; Bussen S.C., Leak R.K., MetzGer L.E., 1988. Response of lactating dairy cows to intramuscular or subcutaneous injection of sometribove, USAN (recombinant methionyl bovine somatotropin) in a 14-day prolonged release system. Part I. Animal Performance and Health. J. Dairy Sci., 71 (suppl. 1), 167 (Abstr.). 